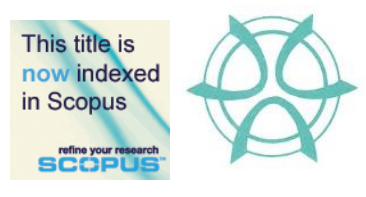

PLANNING MALAYSIA:

Journal of the Malaysian Institute of Planners

VOLUME 17 ISSUE 1 (2019), 58 - 69

\title{
EXPLORATION ON THE DEFINITION AND THE REAL MEANING OF CORPORATE REAL ESTATE TERM
}

\author{
Farahiyah Fadzil ${ }^{1}$ \\ ${ }^{1}$ School of Government \\ UNIVERSITI UTARA MALAYSIA
}

\begin{abstract}
Corporate Real Estate (CRE) is not a new term in the field of property research. In fact, disciplines of CRE research are becoming increasingly widespread nowadays. Consequently, the interpretation of CRE term has undergone a paradigm shift as time goes by. This study explored the definitions of CRE in the eyes of academicians and researchers as well as the meanings of CRE based on Malaysian Accounting Standard Board (MASB). Literatures were chosen to illustrate the breadth of knowledge available regarding the CRE definition. The broad definition of Corporate Real Estate (CRE) term (since 1983 to 2016) has been presented in the form of table. The discussion on the definition of CRE involves four phases, where each phase consists of 10 years. This allowed the researcher to see whether there were any changes or improvements to the definition of CRE in the last 40 years. Then, the CRE meaning was further examined, but from a different perspective. Therefore, content analysis of annual reports prepared by 40 Malaysian non-property public listed companies was conducted in order to identify the CRE term that has been applied in their companies. It was found that the CRE term was not adopted to represent real estate of a particular company. This study managed to identify 29 different terms that represent corporate real estate assets, of which nine (9) are used to represent "building" while six (6) are used to represent "land". However, to understand the CRE of a company, the terms used in the company annual report are insufficient. What is more important is to recognise the information related to the CRE asset value. The information is not only intended to illustrate the wealth of company CRE assets, but also to pinpoint anything that happens to CRE such as depreciation, disposal, etc.
\end{abstract}

Keywords: corporate real estate, land, building 
PLANNING MALAYSIA

Journal of the Malaysia Institute of Planners (2019)

\section{INTRODUCTION}

Corporate Real Estate (CRE) is not a foreign term for companies all around the world since its introduction 30 years ago. In this regard, Zeckhauser and Silverman (1983) definition of CRE is still relevant and is still widely used by many researchers and academicians to describe the real meaning of CRE. According to Zeckhauser and Silverman (1983), corporate real estate can be defined as any land or buildings that are owned by non-property companies. However, according to Brown et al. (1993), the term CRE is not just limited to real estates owned by a company. It is also applicable to any property leased by a company. In addition, CRE also refers to the use of real estate for a company's business operations and any other related activities (Brueggeman \& Fisher, 2001).

Several local researchers have illustrated the real scenario of CRE practises in Malaysia (Iskandar, 1996; Hwa, 2003, 2005; Zaiton, McGreal, \& Adair, 2006; Zaiton, McGreal, Adair, \& Webb, 2008; Marwani \& Zaiton, 2012; Nurul Nabila, Mohd Lizam, Ahmad Kaseri, Abdul Jalil, \& Asmahani, 2015). According to Zaiton et al. (2008), 76\% of Malaysian companies adopted CRE strategies that were in line with the Nourse and Roulac framework (Nourse \& Roulac, 1993). This illustrates the emergence of a trend encouraging CRE practices among these corporations. There were also evidences indicating that CREs were important assets in a company's balance sheet (Hwa, 2005). The study was conducted on the real estate wealth of listed, non-property companies in Malaysia, and found that 35\% of market capitalizations for Bursa Malaysia were sourced from CRE. This amounted to a value of approximately RM216 billion. Besides that, corporate real estate also contributed to $36 \%$ of the net tangible assets, $34 \%$ of the shareholder's equity, $27 \%$ of total capital employed, and $19 \%$ of total tangible assets for public listed companies for the period of 1995-2001 (Hwa, 2005). As evident from these researches, CRE are undoubtedly important for Malaysian companies.

Previous studies were more towards discussing the importance of CRE by looking at the role played by CRE in generating income and creating wealth to the companies. What was rarely done includes giving enlightenment about the true meaning of corporate real estate by discussing on the definition of CRE term. However, further questions arose; why the meaning of CRE should be clearly understood and what is its significance? Previous studies have discussed some of the problems faced by CRE executives due to the lack of knowledge on the field of CRE, which in turn affected the effective communication between the CRE department and the top management of the company.

A study conducted by Lambert, Poteete and Waltch (1995) identified some constraints faced by the CRE executives worldwide with regards to their responsibilities and roles they play in an organisation. These constraints include the lack of power, resources, or required knowledge. In addition, Manning and Roulac (1996) explored the problems experienced by CRE managers with senior 
Farahiyah Fadzil

Exploration on The Definition and The Real Meaning of Corporate Real Estate Term

management and business units' managers to effectively communicate. Ineffective communication can affect corporate strategic planning to maximise company's performance when the creative decision on real estate or operational decision could not be made properly (Manning \& Roulac, 1996).

Thus, the mutual understanding of anything related to a company's CRE should be strengthened so that consensus can be achieved, especially in regards to the company's financial decision making on owning corporate real estates. Rodriguez and Sirmans (1998) pointed out that all decisions related to real estate could affect a company's expected revenue and share prices. Therefore, a CRE officer is generally responsible for convincing senior decision makers in any decisions related to the management of CRE assets so that the property would not be classified as a liability that need to be minimised, rather as an asset than need to be optimised (Lindholm, Gibler, \& Levainen, 2006). However, a study conducted by Krumm and De Vries (2003) found that the effect of real estate decisions can rarely be related to a CRE manager's corporate performance. Thus, they suggest that CRE officers should have better understanding and knowledge to evaluate the true value of a corporate property and the impact of CRE on the company's livelihood.

Hence, to get crystal clear of the real meaning of CRE, this paper explored the definitions of CRE in the eyes of academicians and researchers as well as the meanings of CRE based on Malaysian Accounting Standard Board (MASB).

\section{DEFINITIONS OF CORPORATE REAL ESTATE}

Corporate Real Estate (CRE) is not a new term in the field of property research. In fact, disciplines of CRE research are becoming increasingly widespread nowadays. Consequently, the interpretation of CRE term has undergone a paradigm shift as time goes by.

Table 1 below presents the broad definition of CRE term that has been used since 1983 to 2016. The discussion on the definition of CRE involves four phases, where each phase consists of 10 years. This allows researcher to see whether there were any changes or improvements to the definition of CRE in the last 40 years.

Table 1: Definition of Corporate Real Estate (CRE)

\begin{tabular}{|c|c|c|}
\hline Year & Authors & Definition of CRE \\
\hline 1983 & $\begin{array}{l}\text { Zeckhauser \& } \\
\text { Silverman }\end{array}$ & $\begin{array}{l}\text { The land and buildings owned by companies not } \\
\text { primarily in the real estate business }\end{array}$ \\
\hline 1988 & $\begin{array}{l}\text { Dresdow \& } \\
\text { Tryce }\end{array}$ & Real estate leased and controlled by the corporation \\
\hline 1990 & Nourse & $\begin{array}{l}\text { The management of real property assets for use in } \\
\text { business other than real estate }\end{array}$ \\
\hline
\end{tabular}




\begin{tabular}{|c|c|c|}
\hline 1992 & Joroff & $\begin{array}{l}\text { The land and buildings used for work space, } \\
\text { infrastructure and investment. }\end{array}$ \\
\hline 1993 & Brown et al. & $\begin{array}{l}\text { Corporate real estate management (CREM) is the } \\
\text { optimum use of all real estate assets utilised by a } \\
\text { corporation in pursuit of its primary business mission }\end{array}$ \\
\hline 1993 & Brown et al. & $\begin{array}{l}\text { Real properties that house productive activities of a } \\
\text { company whose primary corporate purpose involves } \\
\text { producing goods and services, but that incidentally } \\
\text { owns and/ or leases and manages real estate to } \\
\text { achieve corporate productions and objectives }\end{array}$ \\
\hline 1999 & O’Mara & $\begin{array}{l}\text { CRE - encompass all aspects of the physical settings } \\
\text { of the organizations }\end{array}$ \\
\hline 1999 & $\begin{array}{l}\text { Nelson, Potter, } \\
\& \text { Wilder }\end{array}$ & $\begin{array}{l}\text { Real estate assets which represent a significant } \\
\text { proportion of firm value. }\end{array}$ \\
\hline 1999 & Roulac & $\begin{array}{l}\text { CRE is real property that house productive activities } \\
\text { of a traditional corporation }\end{array}$ \\
\hline 1999 & Booth & $\begin{array}{l}\text { CRE is the quickest and most direct solution for } \\
\text { companies looking to increase value by controlling } \\
\text { the cost base }\end{array}$ \\
\hline 2000 & Kooymans & $\begin{array}{l}\text { "Corporate Real Estate" is a term that is generally } \\
\text { used in a broad sense to refer to real estate owned by } \\
\text { a corporation, whether it is for investment or for use }\end{array}$ \\
\hline 2001 & $\begin{array}{l}\text { Brueggeman \& } \\
\text { Fisher }\end{array}$ & $\begin{array}{l}\text { The use of real estate as part of business operations } \\
\text { and their activities are commonly referred as CRE }\end{array}$ \\
\hline 2002 & Wills & $\begin{array}{l}\text { Real property assets that is essential for its } \\
\text { production or continuance in business. It does not } \\
\text { include those real property assets that are held for } \\
\text { investment purposes. }\end{array}$ \\
\hline 2003 & $\begin{array}{l}\text { Krumm \& De } \\
\text { Vries }\end{array}$ & $\begin{array}{l}\text { Corporate Real Estate is a substantial asset base and } \\
\text { an important cost factor }\end{array}$ \\
\hline 2010 & $\begin{array}{l}\text { Hartmann, } \\
\text { Linneman, } \\
\text { Pfnur, Moy, \& } \\
\text { Siperstain }\end{array}$ & $\begin{array}{l}\text { Owing to its enormous asset value and associated } \\
\text { costs, real estate is increasingly recognized as an } \\
\text { important competitive factor among non-real estate } \\
\text { related firms. }\end{array}$ \\
\hline 2013 & $\begin{array}{l}\text { Khanna, Van } \\
\text { Der Voordt, \& } \\
\text { Kopples }\end{array}$ & $\begin{array}{l}\text { CRE can be seen as a secondary channel of corporate } \\
\text { communication. }\end{array}$ \\
\hline 2014 & $\begin{array}{l}\text { Abdul Jalil \& } \\
\text { Heywood }\end{array}$ & $\begin{array}{l}\text { CRE contribution move beyond physical contribution } \\
\text { into intangible roles, including human resources and } \\
\text { financial contributions. }\end{array}$ \\
\hline 2016 & Zhao \& Sing & $\begin{array}{l}\text { CRE is the single largest fixed capital investment of } \\
\text { many public listed firms which not substitutable by } \\
\text { other capital goods, such as equipment and plants. }\end{array}$ \\
\hline
\end{tabular}


Farahiyah Fadzil

Exploration on The Definition and The Real Meaning of Corporate Real Estate Term

In the early phase (1981-1990), studies have interpreted that the term of CRE in the simple form and easy to understand. The most common use of CRE definition was introduced by Zeckhauser and Silverman (1983), which refers to land and buildings owned by companies not primarily in the real estate business. Nourse (1990) also defined the CRE as the management of real property assets for use in business other than real estate. If observed carefully, the term "real property assets" used by Nourse (1990) is actually represented by the "land and building" which have been asserted by Zeckhouser and Silverman (1983). In fact, there are also similarities to the phrase "companies not primarily in the real estate business" with "business other than real estate". Both of these definitions explained that CRE involves the function of real estate asset as a factor of production and not the end product of the organisation.

Meanwhile, Dresdow and Tryce (1988) viewed CRE as a real estate leased and controlled by the corporation. This definition translates the meaning of CRE with a different ownership concept where the term "leased" illustrates that the corporation does not necessary own the property asset to run their business operation, but adequate for them to lease the land, building or just a part of business space only. However, the existence of the "controlled" term in the definition should be emphasized because even if the property is just a lease property, but the company must ensure that real estate should be organized in a proper management.

The second phase (1991-2000) shows that CRE has been defined in more detail especially about how CRE plays its role or function in a business organisation. Joroff (1992) described CRE as the land and buildings used for work space, infrastructure and investment. He also claimed that CRE is as strategic a resource as information, employees or technology. In addition, Kooymans (2000) defined CRE as a term that is generally used in a broad sense to refer to real estate owned by a corporation, whether it is for investment or for use. Both definitions shared the same view on the importance of CRE, which is to provide space for working or as an investment alternative for the companies. CRE definition has been expanded with the addition of the "investment" term and became something interesting to be discussed. Both researchers agreed that real estate investment in a business organisation is also part of CRE activities.

Brown et al. (1993) and Roulac (1999) defined CRE as real properties that house productive activities of a company. The main idea to focus is the use of CRE as working space provider either to the goods or services sector. However, there was a continuity in the definition of CRE by Brown in the same year. He indicated that CREM is the optimum use of all real estate assets utilised by a corporation in pursuit of its primary business mission. This time, he tended to incorporate the "management" term when clarifying the meaning of CRE. The significant point in Brown's definition is an effective and efficient management on the utilization of real estate asset. In order to achieve business goal, the highest 
PLANNING MALAYSIA

Journal of the Malaysia Institute of Planners (2019)

and best use of real estate asset which represent the term "optimum" should be implemented.

Meanwhile, O'Mara (1999) defined CRE as encompassing all aspects of the physical settings of the organizations. This definition clearly shows that CRE has numerous functions involving decision relating to real estate such as determining whether to lease or purchase property, determining the location of new office, or deciding on the disposal excess property. Besides that, CRE is also viewed as real estate assets which represent a significant proportion of firm value (Nelson et al., 1999). The real estate asset intensity, which is the total property (land and building) from the total assets of the companies, reflects what is mean by the "significant proportion" term. However, this term also can be interpreted as the proportion of real estate from the total cost of the companies. In addition, Booth (1999) described CRE as the quickest and most direct solution for companies looking to increase value by controlling the cost base. This definition suggests that real estate has a very direct impact upon shareholder value.

Most of the CRE definition in the third phase (2001-2010) emphasized on the significance of CRE. For example, Brueggeman and Fisher (2001) referred to CRE as part of business operations. This definition shared similar meaning of CRE with the definition that was used by Wills in 2002. He defined CRE as real property assets that are essential for its production or continuance in business. However, it does not include those real property assets that are held for investment purposes. Then, the significance of CRE to a firm can be reflected through the definition of CRE given by Krumm and De Vries (2003) where CRE is a substantial asset base and an important cost factor. The term "cost factor" referred to the rising cost of CRE management like rental payment, leased, taxes, utilities and others.

Definition by Krumm and De Vries (2003) was then expanded by Hartmann et al. (2010) when they incorporated the element of "competitive factor" in their CRE definition. They asserted that real estate is increasingly recognized as an important competitive factor among non-real estate related firms due to its enormous asset value and associated costs. In fact, companies around the world faced challenges in coordinating corporate real estate management in recent years.

There has been some improvement in the definition of CRE as interpreted by recent researchers align with the era of globalisation. Khanna et al. (2013) asserted that CRE can be seen as a secondary channel of corporate communication. This definition clearly states that, CRE can be described as a symbol of corporate identity. Establishment of a company on iconic buildings within prime locations will convey messages to their employees, clients and other stakeholders on their corporate branding as well as their values. Meanwhile, a study conducted by Abdul Jalil and Heywood (2014) has defined CRE by considering the contribution of CRE from a holistic perspective. They asserted 
Farahiyah Fadzil

Exploration on The Definition and The Real Meaning of Corporate Real Estate Term

that CRE has undergone a paradigm shift from simply providing workplaces to employees (physical contribution) to diversifying CRE contribution in wide areas (intangible roles) namely, human resources, finances, internal culture development, improved productivity, and marketing. According to the latest research done by Zhao and Sing (2016), CRE is the single largest fixed capital investment of many public listed firms which not substitutable by other capital goods, such as equipment and plants. This definition denies the involvement of plant and equipment when explaining the roles played by CRE since they are not fixed and can usually be moved or relocated.

\section{IDENTIFICATION OF CRE IN PUBLIC LISTED NON-PROPERTY COMPANIES' ANNUAL REPORT}

The earlier discussion on CRE definition only focused on the definitions given by researchers and academicians. In this section, the CRE meaning will be further examined, but from a different perspective. Therefore, content analysis of annual reports of 40 Malaysian non-property public listed companies was conducted in order to identify the CRE term that has been applied in their companies.

According to the annual reports prepared by Malaysian corporate firms, the CRE term was not adopted in the Financial Statements to represent real estate of a particular company. However, in the corporate world, especially in Malaysia, the use of Property, Plant and Equipment (PPE) term is more synonymous to describe matters associated with real estate elements. Normally, a detailed description of the PPE value which is presented in the company annual report can be found in the Statements of Financial Position. In specific, it falls under the category of Notes to the Financial Statements, which is also known as Significant Accounting Policies. In fact, some important aspects related to PPE are specifically emphasised; cost, depreciation, impairment, gains or losses on disposal, asset exchange transaction as well as repairs and maintenance.

According to the Malaysian Accounting Standard Board Standard 15 (MASB, 2000), PPE is defined as tangible assets that:

(i) are of held by a company for use in the production or supply of goods or services, for rental to others, or for administrative or maintenance purposes

(ii) are expected to be used during more than on reporting period.

This definition indicates that, PPE is operating fixed assets which are used for operations of the business on a continuing basis in order to generate revenues. There are two indicators that have been used by MASB15 in the recognition of PPE; an item of PPE should be recognised as an asset when it is probable that future economic benefits associated with the asset will flow to the company and the cost of the asset to the enterprise can be measured reliably.

When land and building are to be recognised as assets, the initial cost of the land and building as fixed assets will include the costs of bringing the land 
PLANNING MALAYSIA

Journal of the Malaysia Institute of Planners (2019)

and building into working condition for their intended use such as the cost of site preparation, installation, set-up, etc. In order to classify items of PPE, CRE assets have been categorized in accordance with the similar nature of use of those assets in the operations of a company. Examples of separate classes that encompass CRE assets of PPE are provided in MASB15 (item 41) as "land" and "land and buildings". However, this does not mean that the CRE definition in annual report is only bound by the term "land and buildings".

In fact, according to the outcome of the content analysis of annual reports, there are other terms that are used in the company annual reports to define CRE. Table 2 shows the PPE classification that is related to CRE.

Table 2.2: Classes of PPE that Relate to CRE Assets

\begin{tabular}{|c|c|c|}
\hline $\begin{array}{c}\text { The classification } \\
\text { of CRE }\end{array}$ & $\begin{array}{l}\text { The terms used to represent } \\
\text { CRE assets }\end{array}$ & $\begin{array}{c}\text { The number of companies } \\
\text { that use the terms }\end{array}$ \\
\hline \multirow[t]{6}{*}{ Land } & Land & 1 \\
\hline & Freehold land & 27 \\
\hline & Leasehold land & 7 \\
\hline & Long term leasehold land & 13 \\
\hline & Short Term Leasehold Land & 8 \\
\hline & $\begin{array}{l}\text { Prepaid land and land } \\
\text { improvements }\end{array}$ & 1 \\
\hline \multirow[t]{9}{*}{ Buildings } & Buildings & 26 \\
\hline & Building on freehold land & 2 \\
\hline & $\begin{array}{l}\text { Buildings on long term } \\
\text { leasehold land }\end{array}$ & 1 \\
\hline & Freehold Building & 4 \\
\hline & Leasehold buildings & 2 \\
\hline & Long term leasehold building & 1 \\
\hline & Buildings and civil works & 1 \\
\hline & Buildings and improvements & 2 \\
\hline & $\begin{array}{l}\text { Buildings, factory and civil } \\
\text { works }\end{array}$ & 1 \\
\hline \multirow[t]{5}{*}{ Land and Buildings } & Land and Buildings & 2 \\
\hline & Freehold Land and Building & 2 \\
\hline & Long Leasehold Land and & 1 \\
\hline & $\begin{array}{l}\text { Building } \\
\text { Short Leasehold Land and }\end{array}$ & \\
\hline & Building & 1 \\
\hline \multirow[t]{4}{*}{ Others CRE } & Freehold Estates & 1 \\
\hline & Freehold Estates Land & 1 \\
\hline & Oil Palm Plantation & 1 \\
\hline & Workshop & 1 \\
\hline
\end{tabular}


Farahiyah Fadzil

Exploration on The Definition and The Real Meaning of Corporate Real Estate Term

Based on Table 2 above, there are 29 different terms that represent corporate real estate assets, of which nine (9) are used to represent "building" while six (6) are used to represent "land". In general, most corporations tend to only use the term "building" in the PPE classification. However, when it comes to the use of the term "land", the situation is different. This is because, most of the companies will particularise more information regarding the type of land tenure, either freehold or leasehold. If the land is leasehold, some companies state the lease period, either short term or long term leasehold. Besides, there are some companies that take CRE report lightly, in which the terms are combined as "land and buildings" in the PPE note section. This means that separate information regarding the real value of "land" and "building" cannot be identified in a transparent manner.

Simpson and McDonagh (2010) identified that there were 40 separate classes that have been used by various public listed companies in reporting the CRE assets. They found that there was a lack of consistency by management in naming separate classes and their results also revealed that management were confused as to whether or not to separate out freehold and leasehold of CRE assets.

However, to understand the CRE of a company, the terms used in the company annual report are insufficient. What is more important is to recognise the information related to the CRE asset value. The information is not only intended to illustrate the wealth of company CRE assets, but also to pinpoint anything that happens to CRE such as depreciation, disposal, etc. Thus, it is crucial for researchers to master the basic methods in identifying CRE in company's Financial Statements.

\section{CONCLUSION}

Discussion in this paper was divided into two major parts. It began with a review of CRE definition by exploring the real meaning of CRE in the eyes of academicians and researchers. In order to see whether there were any changes or improvements to the definition of CRE in the last 40 years, broad definition of CRE term that has been used since 1983 to 2016 was presented. This study has identified that the interpretation of CRE term has undergone a paradigm shift as time goes by, where CRE can be defined as any land or buildings that are owned or leased by non-property companies which can be used for a company's business operations and any other related activities.

Then, the CRE meaning is further examined from different perspective in order to identify definitions used to represent real estate assets, as stated in the selected companies' annual reports. As a result, the terms such as PPE were more synonymous in the corporate world. However, based on the PPE classification associated with CRE, there were 29 terms that have been used to represent "land" and "building". This study also found that separate information regarding the real 
value of "land" and "building" cannot be identified in a transparent manner because of there were some companies that take CRE report lightly. Besides that, inconsistencies in naming separate classes have also became one of the issues faced by some corporate companies.

In conclusion, this study has made several contributions to the knowledge base of CRE. The main contribution of this study is the exploration on the paradigm shift of the broad definition of CRE. This study also serves as a future reference for academicians or researchers on the clarification of the terms that have been used in representing CRE in Malaysian companies' annual report. Therefore, a better understanding to evaluate the true value of a corporate property will be mastered by having enlightenment about the true meaning of CRE.

\section{REFERENCES}

Abdul Jalil, O., \& Heywood, C. A. (2014). Defining a corporate real estate management's (CREM) brand. Journal of Corporate Real Estate,16(1), 60-76.

Booth, M. (1999). How corporate real estate affects shareholder value?. Journal of Corporate Real Estate, 2(1), 19-28.

Brown, R. K., Arnold, A. L., Rabianski, J. S., Lapides, P. D., Rondeau, E. P., \& Rhodes, M. S. (1993). Managing corporate real estate: Forms and procedures. New York: John Wiley and Sons.

Brueggeman, W. B., \& Fisher, J. D. (2001). Real estate finance and investments. New York: McGraw-Hill.

Dresdow, G., \& Tryce, R. (1988). Today's corporate real estate demands better management. National Real Estate Investor, 30(10), 87-90.

Hartmann, S., Linneman, P., Pfnur, A., Moy, D., \& Siperstain, B. (2010). Responsibility for and performance of corporate real estate functions. Journal of Corporate Real Estate, 12(1), 7-25.

Hwa, T. K. (2003, January). The reorganisation and restructuring of corporate real estate. $9^{\text {th }}$ Pacific Rim Real Estate Society Annual Conference. January 20-22, 2003, Brisbane, Australia.

Hwa, T. K. (2005). Corporate real estate of an emerging market: Evidence from bursa Malaysia. 12th Annual European Real Estate Society (ERES) Conference. Dublin, Ireland.

Iskandar, I. (1996). The operational property management process in large non-property organisations in Malaysia: An organisational perspective (Doctoral dissertation). University of Reading, UK.

Joroff, M. (1992). Corporate real estate 2000, management strategies for the next decade. Norcross, Ga.: Industrial Development Research Foundation White Paper.

Khanna, C., Van Der Voordt, T. J. M., \& Kopples, P. W. (2013). Corporate real estate mirrors brand: A conceptual framework and practical applications. Journal of Corporate Real Estate, 15(3/4), 213-230.

Kooymans, R. (2000, January). The outsourcing of corporate real estate management how do corporate real estate units and outsource service providers view each 
Farahiyah Fadzil

Exploration on The Definition and The Real Meaning of Corporate Real Estate Term

other and the management issues?. Sixth Annual Pacific Rim Real Estate Society Conference. January 24-27, 2000, Sydney, Australia.

Krumm, P. J. M. M., \& De Vries, J. (2003). Practice briefing: Value creation through the management of corporate real estate. Journal of Property Investment \& Finance, 21(1), 61-72.

Lambert, S., Poteete, J., \& Waltch, A. (1995). Generating high-performance corporate real estate service. Corporate Real Estate 2000 Series Report No. 52, Industrial Development Research Foundation, Norcross, GA.

Lindholm, A. -L., Gibler, K. -M., \& Levainen, K. -I. (2006). Modeling the value-adding attributes of real estate to the wealth maximization of the firm. Journal of Real Estate Research, 28(4), 443-475.

Malaysian Accounting Standards Board (2000). Property, plant, and equipment: MASB standard 15 (MASB15). Kuala Lumpur: Author.

Manning, C. A., \& Roulac, S. E. (1996). Structuring the corporate real property function for greater 'bottom line' impact. Journal of Real Estate Research, 12(3), 383396.

Marwani, M. R., \& Zaiton, A. (2012). Determining factors of corporate real estate (CRE) strategy implementation in the Malaysian business corporations. International Journal of Real Estate Studies, 7(1).

Nelson, T. R., Potter, T., \& Wilde, H. H. (1999). Real estate assets on corporate balance sheets. Journal of Corporate Real Estate, 2, 29-40.

Nourse, H. O. (1990). Managerial real estate, corporate real estate asset management. Englewood Cliffs: Prentice Hall.

Nourse, H. O.\& Roulac, S. E. (1993). Linking real estate decisions to corporate strategy. Journal of Real Estate Research, 8(4), 475-94.

Nurul Nabila, S., Mohd Lizam, M. D., Ahmad Kaseri, R., Abdul Jalil, O., \& Asmahani, A. (2015). Corporate real estate performance in Malaysian public listed companies. 21st Annual Pacific-Rim Real Estate Society Conference. January 18-21, 2015, Kuala Lumpur, Malaysia.

O’Mara, M. A. (1999). Strategy and place: Managing Corporate Real Estate and Facilities for Competitive Advantage. New York: The Free Press.

Rodriguez, M., \& Sirmans, C. F. (1998). Effects of Corporate Real Estate Decisions on Company Values. Corporate Real Estate Executive, July-August, 30-33.

Roulac, S. E. (1999). Real estate value chain connections: Tangible and transparent. Journal of Real Estate Research, 17(3), 387-404.

Simpson, J. H., \& McDonagh, J. (2010). Financial reporting on corporate real estate: a study of the annual reports of non-investment companies listed on the New Zealand Stock Exchange (NZSE). 16th Pacific Rim Real Estate Society Conference, Wellington, New Zealand.

Wills, P. C. (2002). Increasing shareholder value through quality corporate real estate management. Pacific Rim Real Estate Society Eight Annual Conference. Christchurch, New Zealand.

Zaiton, A., McGreal, S., Adair, A., \& Webb, J. (2008). Corporate real estate strategy: The Malaysian perspective", Journal of Real Estate Literature, 16(1), 33-54.

Zaiton, A., McGreal, S., \& Adair, A. (2006). Corporate real estate strategy in the UK and Malaysia. Journal of Corporate Real Estate, 8(4), 168-177. 
PLANNING MALAYSIA

Journal of the Malaysia Institute of Planners (2019)

Zeckhauser, S. \& Silverman, R. (1983). Rediscover your company's real estate. Harvard Business Review, 61(1), 111-117.

Zhao, D., \& Sing T. F. (2016). Corporate real estate ownership and productivity uncertainty. Real Estate Economics, 44(2), 521-547

Received: $28^{\text {th }}$ October 2018. Accepted: $1^{\text {st }}$ March 2019 